
doi: http://dx.doi.org/10.33369/....

\title{
Pembelajaran Pendidikan Kewarganegaraan Berbasis Pendidikan Nilai
}

\section{Puspa Djuwita}

Fakultas Keguruan dan Ilmu Pendidikan

Puspadjuwita1958@gmail.com

\begin{abstract}
Pengembangan materi ajar merupakan hal yang sangat penting dalam aktivitas pendidikan. Tanpa adanya materi pembelajaran, kegiatan pendidikan tidak akan dapat terjadi. Oleh sebab itu materi ajar perkuliahan wajib diinovasi, karena kebutuhan akan keterbaharuan pengetahuan merupakan hal yang penting, apa lagi dengan pesatnya perkembangan kehidupan masyarakat global pada abad 21, di mana setiap saat terjadi perubahan pola kehidupan dalam hubungan berbangsa dan bernegara sesuai dengan perkembangan zaman, berdampak pada perkembangan ilmu pengetahuan disertai oleh kemajuan bidang informasi dan teknologi dalam pembelajaran, yang begitu pesat. Penelitian pengembangan materi ajar pembelajaran Sekolah Dasar (SD) bidang PKn bertujuan untuk; [a] melakukan pengembangan bahan ajar mata kuliah pengembangan pembelajaran $S D$ bidang PKn berbasis pendidikan nilai, [b] terwujudnya bahan perkuliahan pengembangan pembelajaran PKn berbasis pendidikan nilai dengan konten yang kekinian, tanpa mengurangi esensi konten pembelejaran PKn selama ini, [c] tersedianya referensi pengembangan pembelajaran bidang PKn SD berbasis pendidikan nilai yang dapat digunakan sebagai acuan mahasiswa yang mengambil perkuliahan konsentrasi PKn, dan penyelesaian tugas akhir, [d] tersedianya variasi refrensi bahan ajar pengembangan pembelajaran bidang PKn yang pas bagi mahasiswa pasca sarjana. Penelitian ini dirancang dengan menggunakan pendekatan penelitian pengembangan (Resarch and Development), Teknik pengumpulan data, yaitu; wawancara, dokumentasi. Analisis menggunakan teknik analisis data kualitatif. Analisis dilakukan terhadap data kebutuhan mahasiswa terhadap konten bahan ajar pengembangan pembelajaran $P K n S D$, dan analisis terhadap pendekatan strategi, dan model penidikan nilai mana yang dapat diintegrasikan sebagai konten dalam bahan ajar pengembangan pembelajaran PKn. Hasil penelitian diperlukan penamabahan materi tentang pendidikan nilai dalam pembelajaran bidang PKn. Implikasi dari tersusunnya bahan ajar bidang PKn SD ini dapat menambah wawasan dan dapat dimanfaatkan maha siswa dalam melaksanakan kuliah konsentrasi PKn, dan menyelasaikan tugas akhir (tesis) bagi yang memilih kajian pembelajaran PKn Simpulan penelitian antara lain; bahan ajar pembelajaran PKn telah dapat disusun dalam bentuk draf yang akan dijadikan buku ajar.
\end{abstract}

Kata kunci: pembelajaran, PKn, berbasis, nilai 


\section{Pendahuluan}

Salah satu aspek yang tidak bisa diabaikan dalam kegiatan pendidikan adalah tersedianya sumber belajar berupa bahan ajar (teaching material) yang sesuai dengan kebutuhan peserta didik dan tuntutan perkembangan ilmu pengetahuan bidang pembelajaran.Tidak satupun dikalangan pendidik menganggap bahan ajar bukanlah suatu yang urgen, semuanya pastilah yakin bahwa salah satu indikator keberhasilan proses pembelajaran adalah tersedianya bahan pembelajaran. Bahan pembelajaran (teaching material) merupakan hal yang sangat penting dalam aktivitas pendidikan. Tanpa adanya materi pembelajaran, kegiatan pembelajaran tidak bisa dilaksanakan. Materi pembelajaran itu, wajib selalu dikembangkan sesuai dengan perkembanga ilmu pengetahuan dan kebutuhan perkembangan peserta didik. Kebutuhan akan keterbaharuan pengetahuan merupakan hal yang wajib, dalam berhadapan dengan pesatnya perkembangan ilmu pengetahuan pembelajaran modern saat ini. Untuk itu kajian bahan ajar yang mebahas bagaimana membelajarkan bidang-bidang studi IPA, IPS, Bahasa Indonesia, Matematika dan PKn wajib direkayasa sedemikian rupa agar mampu memenuhi kebutuhan pembelajaran sesuai dengan filosufi dikembangkannya kurikulum 2013 di sekolah dasar. Salah satu bidang studi yang sangat mendapat perhatian dalam mempersiapkan warga negara yang cerdas sekaligus memiliki kepribadian bangsanya adalah, bidang studi PKn.

Kemampuan membelajarkan PKn yang terintegrasi dengan bidang studi lain sesuai dengan kurikulum 2013 wajib dikuasai oleh mahasiswa program studi pendidikan dasar. Sebagaimana yang diketahui bahwa muatan pembelajaran yang diinginkan K13 lebih mengutamakan peserta didik memiliki kompetensi inti yaitu kompetensi kepribadian, sosial, dan ketrampilan. Untuk itu mahasiswa sebagai guru atau pun calon guru wajib dibekali materi pembelajaran PKn yang berbasis pada pendidikan nilai, yang mendidik, membina, dan mengembangkan kepribadian. Supaya siswa memiliki kompetensi inti tersebut. Guru wajib menanamkan nilai-nilai melalui pembelajaran, terutama pada tema dan sub tema pembelajaran yang memuat bidang PKn. Mata kuliah pembelajaran Pendidikan Kewarganegaraan Sekolah Dasar sebagai mata kuliah wajib bagi mahasiswa magister pendidikan dasar dan juga akan menjadi bekal ketika melaksanakan tugas praktik lapangan ke sekolah dasar. Disamping itu merupakan bidang kajian pada saat tugas akhir. Berdasarkan pengalaman dilapangan hampir semua guru mengajarkan PKn sama halnya dengan membelajarkan IPA, IPS, Matematika, dengan pendekatan dan model pembelajaran yang sama, yang lebih menekankan pada kemampuan penalaran. Sedangkan pembelajaran $\mathrm{PKn}$ tidak dapat menafikan proses pengembangan kepribadian (sebagaimana dikehendaki rumusan kompetensi inti) sarat muatan nilai yang membina siswa berperilaku sesuai dengan falsafah dan budaya bangsa.

Tidak dapat dipungkiri bahwa kualitas pembelajaran serta hasil belajar salah satunya dipengaruhi oleh kualitas bahan ajar yang dimanfaatkan. Bahan ajar yang sesuai dengan kebutuhan peserta didik saat kegiatan pembelajaran akan memudahan pemahanan terhadap konsep, fakta, prosedur, prinsip yang disajikan dalam bahan ajar, dan melalui pemahanan itu akan terserap atau terintegrasi nilainilai yang membentuk sikap dan pemilikan suatu keterampilan pembelajar. Pengorganisasian materi secara sistematis akan mendorong dan memotivasi peseta didik untuk menguasai materi bahan ajar yang berdampak terhadap penguasaan kompetensi sehingga dapat mencapai tujuan yang diharapakan dari proses pembelajaran. Bahan ajar (teaching material) disebut juga instructional materials, learning material, material, yang dipandang sebagai materi yang disediakan untuk kebutuhan, pembelajaran yang mencakup buku teks dan alat bantu audio visual (Yaumi Muhammad; 2013; 271). Secara teknis bahan ajar dapat dikembangkan atau didesain sebagai representasi penjelasan dosen, juga beperan sebagai pengarah kegiatan pembelajaran dalam mencapai target dan sasaran yang hendak dicapai. 
Pesan atau informasi yang hendak disampaikan dapat dihimpun dalam bahan pembelajaran. Disamping itu bahan ajar sebagai alat dan sarana mencapai stndar kompetensi yang telah ditentukan. Bahan pembelajaran menempati posisi yang sangat penting dari keseluruhan muatan kurikulum, yang harus dipersiapkan agar pelaksanaan pembelajaran dapat mencapai sasaran. Artinya, materi yang ditentukan untuk kegiatan pembelajaran hendaknya benar-benar menunjang tercapainya tujuan (kompetensi).

Pentingnya pengembangan bahan ajar ini mencakup tiga aspek, yaitu sebagai; (1) representasi sajian dosen, (2) sebagai sarana pencampaian kompetensi, dan (3) sebagai optimalisasi pelayanaan pada peserta didik. Adapun kedukukan bahan ajar pada umumnya dapat membantu belajar secara individu, memberikan keluasan dalam penyajian pembelajaran baik jangka pendek maupun jangka panjang, rancangan bahan ajar yang sistematis memberikan pengaruh yang besar bagi peningkatan sumber daya manusia secara indivial, memudahkan proses pembelajaran dengan pendekatan sistem, serta memudahkan belajar karena dirancang berdasarkan kebutuhan pembelajar.

Keberhasilan pembelajaran secara keseluruhan sangat tergantung pada keberhasilan merancang konten bahan pembelajaran. Secara garis besar konten bahan pembelajaran (instructional materials) terdiri atas; (1) pengetahuan,yang berhubungan dengan fakta, konsep, prinsip, dan prosedur; (2) sikap atau nilai yang harus dikuasai peserta didik dalam rangka mencapai kompetensi yang ditetapkan, dan (3) keterampilan. Konten bahan pembelajaran hendaknya dipilih selengkap mungkin untuk membantu pesertadidik mencapai tujuan pembelajaran yang telah ditetapkan. Hal-hal yang perlu diperhatikan berkenaan dengan penentuan konten bahan pembelajaran yaitu; jenis, cakupan, urutan, dan perlakuan (treatment) terhadap materi pembelajaran tersebut. Prinsip-prinsip yang menjadi acuan dalam menentukan konten materi pekuliahan adalah; kesesuaian (relevansi), keajegan (konsistensi), dan kecukupan (adequacy).

Tujuan Pembelajaran PKn ; (a) untuk meningkatkan kesadaran dan kemampuan diri peribadi siswa sebagai insan pancasilais, (b) untuk meningkatkan diri siswa sebagai warga negara yang pancasilais yang mahir dalam hubungan sosial (Darmadi, 2012: 30). Sedangkan menurut Winarno, tujuan pembelajaran PKn adalah menanamkan sikap dan perilaku yang didasarkan kepada nilai-nilai Pancasila dalam kehidupan sehari-hari, baik sebagai pribadi maupun sebagai anggota masyarakat (2009: 5), sesuai dengan Permendikdas No. 22 Tahun 2006, tujuan PKn adalah untuk memberikan kompetensi-kompetensi; (a) Berpikir secara kritis, rasional, dan kreatif dalam menaggapi isu kewarganegaraan. (b) Berpartisipasi secara aktif dan bertanggung jawab, dan bertindak secara cerdas dalam kegiatan bermasyarakat, berbangsa, dan bernegara serta anti korupsi. (c) Berkembang secara positif dan demokratis untuk membentuk diri berdasarkan karakter-karakter masyarakat Indonesia agar dapat hidup bersama dengan bangsa-bangsa lain. (d) Berinteraksi dengan bangsa-bangsa lain dalam peraturan dunia secara langsung atau tidak langsung dengan memanfaatkan teknologi informasi dan komunikasi. (Fathurrohman dan Wuri (2011: 7). Bedasarkan pendapat-pendapat ini, maka dapat maknai bahwa bahan ajar PKn hendaknya mengakomodir tujuan pembelajaran yang akan mengahsilkan peserta didik mampu berpikir kritis, berpartisipasi secara aktif dan bertanggung jawab, warga negara yang demokrasi dalam berinteraksi dengan semua orang baik sesama anak bangsa maupun dengan warganegara bangsa lain dalam lingkup masyarakat global abad 21.

\section{Metode}

Penelitian ini dirancang dengan menggunakan pendekatan penelitian pengembangan (Resarch and Development), dengan langkah kerja penelitian dimulai dari; (a) 
melakukan need asssessment, (b) merumuskan kompetensi lulusan, (c) membuat draf materi ajar yang kontennya berbasis pendidikan nilai, (d) validasi pakar, (e) revisi berdasarkan hasil validasi pakar, (f) uji coba terbatas, (g) revisi berdasarkan uji coba, dan (h) uji coba secara luas, (i) revisi berdasarkan uji secara luas, (k) mencetak bahan ajar dalam bentuk buku. Sumber informasi penelitian adalah mahasiswa yang sudah menepuh matah kuliah pengembangan pembelajaran PKn Sekolah dasar, alasan mengapa mereka yang dipilih sebagi sumber informasi dikarenakan mereka akan dapat memberikan informasi kebutuhan bahan ajar bidang Pendidikan Kewarganegaraan. Disamping itu karena mereka sudah menjadi guru lebih dari 5 tahun, menurut peneliti mereka tahu persis kebutuhan pengetahuan bagi pelaksanan pembelajaran di SD utamanya pada materi Pendidikan Kewarganegaraan. Selain para mahasiswa, sumberdata lain adalah refrensi yang telah ada untuk dikaji bagian mana yang perlu dikembangkan untuk menghasilkan bahan ajar yang sesuai bagi mahasiswa pasca sarjana magister pendidikan dasar.

\section{Teknik Pengumpulan Data}

Teknik pengumpulan data dalam penelitian ini menggunakan, wawan cara dan dokumentasi. Instrumen pengumpulan data berupa pedoman, wawancara, dan dokumentasi. Wawancara mendalam dilakukan untuk mengetahui kebutuhan mahasiswa terhadap konten bahan ajar pembelajaran SD bidang PKn. Dokumentasi dilakukan untuk menelaah konten bahan ajar pembelajaran SD bidang PKn yang telah ada. Juga melakukan mengidentifasi konten apa saja yang wajib ada dalam materi kuliah, serta data tambahan yang berhubungan dengan konten pembelajaran SD bidang PKn.

\section{Teknik Analisis Data}

Analisis penelitian menggunakan teknik analisis data kualitatif meliputi; reduksi data, display data, verifikasi dan kesimpulan. Analisis dilakukan terhadap data kebutuhan mahasiswa terhadap konten bahan ajar pembelajaran PKn SD, dan analisis terhadap konsep-konsep pendidikan nilai mana yang dapat diintegrasikan dalam pembelajaran SD bidang PKn.

\section{Hasil dan Pembahasan}

\section{Need assessment Bahan Ajar Pembelajaran Bidang PKn}

Sebagian dari mahasiswa ternyata mengangap bahwa materi perkuliahan PKn SD yang telah mereka terima sudah memadai sebagai bekal pengetahuan pendidikan kewarganegaraan yang dapat mereka implementasikan dalam melaksankan tugasnya. Hal ini dikarenakan dosen pengampu matakuliah PKn SD selama ini sudah melakukan beberapa pengembangan materi dengan jalan mengintergasikan beberapa konten dari berbagai sumber yang tersedia. Di samping itu pada umumnya mahasiswa pasca sarjana pendidikan dasar yang mengikuti perkuliahan, sebagian masih bersetatus calon guru, mereka setamat dari pendidikan sarjana (S-1) langsung melanjutkan pendidikan ke jenjang pasca sarjana, sehingga mereka merasakan bahwa materi yang mereka dapatkan dalam kuliah di pasca sarjana pada dasarnya kajiannya lebih banyak memuat integrasi antara konsep dasar dengan implementasinya bagi pendidikan kewarganegaraan pada sekolah dasar. Sedangkan usulan dari enam orang mahasiswa. Mereka sudah melaksanakan tugas keguruannya, yang membutuhkan adanya pendidikan karakter dalam materi PKn SD, hal ini menurut hemat peneliti disebabkan mereka menganggap bahwa materi pembelajaran PKn lebih berat pada konsep tentang kewarganegaraan dari pada pendidikan pengembangan karakter (kepribadian).

Usulan dari empat orang mahasiswa yang mengharapkan adanya materi yang membahas tentang nilai-moral dan norma Pancasila, dengan alasan yang hampir 
sama dengan keenam mahasiswa tersebut di atas. Mereka menginginkan konsep nilai-moral- norma Pancasila agar lebih ekplisit atau lebih nyata ada bahsannya. Ini disebabkan masih minimnya pengetahuan dan pemahaman mereka tentang pendidikan nilai-nilai, moral dan norma Pancasila, karena belum mendapatkan pengetahuan yang mantap tentang nilai-moral, norma serta cara mendidikankanya melalui pendidikan kewarganegaraan agar nilai-nilai- moral- norma dapat terintegrasi dalam diri peserta didik sekolah dasar pada proses pemebelajaran pendidikan kewarganegaraan di kelas.

\section{Pengembang Bahan Ajar Pembelajaran Bidang PKn SD}

Setelah diketahui kebutuhan mahasiswa terhadap materi perkuliahan pendidikan kewarganegaraan dan didapatkan materi-materi seperti di atas, maka peneliti mencoba menyusunnya sedemikan rupa agar sistematis, mudah dipelajari, sehingga akan mudah pulah dicernah dan dipahami. Isi materi yang telah tersusun dalam draf tersebut kemudian dilakukan pembenahan disana sini agar lebih mudah dipelajari. Ini dilakukan agar supaya mahasiswa lebih mudah untuk mengaplikasikannya dalam rancangan desain pembelajaran ketika mereka melaksanakan kuliah praktik di sekolah dasar. Draf yang sudah tersusun menurut hemat peneliti sudah dapat digunakan walaupun belum sempat dilakukan validasi pakar, tidak terlaksananya validasi ini ditenggarai sulitnya menemukan pakar dari luar Fakultas dan atau Universitas di Provinsi Bengkulu. Memang dosen mata kuliah PKn banyak namun pada umumnya mereka tidak memiliki latar belakang pendidikan formal bidang studi PKn. Di Fakultas dan Universitas hanya ada dua tiga orang saja yang memiliki latar belakang pendidikan formal dalam bidang studi pendidikan kewarganegaraan dan pendidikan nilai, namun para pakar tersebut sangat sulit membagi waktunya karena padatnya kegiatan pendidikan profesi guru dan kegiatan lain di luar kampus. Kendala inilah yang menyebabkan draf ini belum dilakukan validasi pakar. Harapan peneliti kegiatan ini bisa dilanjutkan pada penelitian tahun berikut sehingga draf ini bisa mendapat masukan yang bertambah baik, baik dari segi konsep, maupun dari segi kerbacaannya. Dengan demikian draf yang sudah dihasilkan ini layak cetak menjadi sebuah buku teks yang akan menambah variasi refrensi sumber ajar pendidikan kewarganegaraan.

\section{Konten Bahan Ajar Pembelajaran PKn SD Yang Berbasis Pendidikan Nilai}

Draf bahan ajar yang dirancang dalam beberapa bab yang memuat konten tentang; (a) perkembangan pembelajaran PKn di Indonesia, terdiri dari; perkembangan kurikulum pembelajaran PKn di Indonesia; (b) pembelajaran Pendidikan Kewarganegaraan di era 5.0, yang memuat; paradigma pembelajaran holistik dan paradigma pendidikan karakter nilai budaya; (c) pendakatan, strategi, dan model pendidikan nilai, memuat; pendekatan pendidikan pendidikan nilai dalam pembelajaran PKn, Model-model pendidikan nilai terdiri tiga rumpun model, yaitu; caring, judging dan acting. (d) Evaluasi pembelajaran PKn berbasis pendidikan nilai, yang memuat; teknik penilaian PKn, prinsip-prinsip penilaian, langkah-langkah praktis pengembangan penilaian sikap beserta contoh instrumen observasi dan penilaian diri. Evaluasi pendidikan nilai ini selain observasi dan penilaian diri juga wajib ada penilaian pengetahuan dan keterampilan. namun tidak diberikan contoh, dengan alasan bahwa pembelajaran PKn seharusnya lebih besar porsi pendidikan nilai pembangun karakter, sehingga porsi penilaian sikapnya wajib lebih difokuskan. Konsep-konsep yang telah penulis laporkan di atas. Selanjutnya disusun sedemikian rupa dengan mempertimbangan urutan yang logis, rasional dan sistematis, yang akhirnya terwujudlah suatu draf yang akan divalidasi oleh pakar. 


\section{Kesimpulan}

Peneliti mendapatkan simpulan dari kegiatan penelitian sebagai berikut;

(1) mahasiswa pasca sarjana pendidikan dasar membutuhkan penambahan materi konsep pembelajaran pendidikan nilai pada materi pembelajaran bidang PKn Sekolah Dasar (SD); (2) pengembangan bahan ajar dilakukan berpedoman dari refrensi yang ada dengan penambahan pendidikan nilai mulai dari pendekatan, model-model dan metode pendidikan nilai. (3) bahan ajar yang susun baru berupa draf yang secara garis besar isinya adalah; (a) perkembangan pembelajaran PKn di Indonesia, (b) pembelajaran Pendidikan Kewarganegaraan di era 5.0, (c) pendekatan, strategi, dan model pendidikan nilai, (d) Evaluasi pembelajaran PKn berbasis pendidikan nilai Kesimpulan merupakan jawaban atas pertanyaan penelitian atau rumusan masalah yang telah dikemukakan di awal

\section{Saran}

Bahan ajar perkuliah pengembangan pemebelajaran SD bidang PKn yang sudah dihasilkan ini masih jauh dari sempurna, sebaiknya perlu diperluas dengan materi lain antra lain, materi tentang peran guru PKn dalam mengembangkan kepribadian peserta didik dalam pembelajaran PKn yang terintegrasi dengan bidang studi lain dalam kurikulum 2013. Selain itu waktu penelitian tidak cukup memadai untuk melaksanakan semua rancangan penelitian yang telah dibuat, mungkin perlu penambahan waktu.karena draf ini belum selesai divalidadasi ahli. Sebaiknya untuk melakukan validasi pakar, mencari validator di luar Institusi atau di luar provinsi, misalnya pada Perguruan Tinggi yang memiliki banyak pakar berlatar belakang pendidikan formal dalam bidang kajian PKn dan pendidikan nilai.

\section{Referensi}

Ahmad Rieska. 2014. Problems And Developing Materials of Guidance \&Counseling Base on Building Character. Artikel. Proceeding 2014 Education International Seminar. Padang : Sukabina

Borg, W. R., Gall, M.D., Joyce, P. 2003. Educational Research An Introduction. Seventh Edition.Boston: Pearson Education, Inc.

Creswell, J. W. 1998. Qualitative Inquiry And Research Design Choosing Among Five Traditions. London: Sage Publications.

Djuwita. Puspa. 2005. Pewarisan Budaya Belagham Melalui Pendidikan Dan PersonalisasiNilai Dalam Keluarga (studi kasus dalam upaya menemukan model pewarisan Budaya belagham suku serawai di Bengkulu Selatan). Disertasi tidak diterbitkan

Gunawan Ansyori. 2014. Pengembangan Model Bahan Ajar Melalui Pendekatan Kreatif Produktif Pembelajaran Geometri dan Pengukuran Berbasis Karakter.

Artikel. Proceeding 2014 Education International Seminar. Padang : Sukabina Hakam Kama Abdul. (2003). Pendidikan Nilai. Bandung: Value Press

Jasmadi, dkk. 2008. Panduan Menyusun Bahan Ajar Berbasis Kompetensi. Jakarta: PT Elex Media Komputindo

Living Values. 2004. Purpose And Aims. (Online). Tersedia: http://www. Living Values Education. net/Purpose and Aims-Values Education for Children and Young Adult (24 Juni 2004)

Mulyana. Rt. 2004. Mengartikulasikan Pendidikan Nilai. Bandung: Alfabeta. 
Prastomo. Adi. 2011. Panduan Kreatif Membuat Bahan ajar Inovatif. Jakarta: Diva Press Siahan, Bistok. 1987. Pengembangan Materi Pengajara Bahasa FPS. Jakarta: PP-LPT.

Siddiq, M. Djauhar dkk (2008) Pengembangan Bahan Ajar. Direktorat Jenderal Pendidikan Tinggi DEPDIKNAS.

Smith, Mark. K. 1988. Developing Youth Work. Open University Press

Sutikno Yadi. 2014. Development Text-Base Learning Of Indonesian Language In

Formation Of Character Students. artikel Proceeding 2014 Education International Seminar. Padang : Sukabina

Widodo. Chomsin S. 2008. Panduan Menyusun Bahan Ajar Berbasis Komputer. Jakarta: Media Komputindo

Yaumi Muhammad. 2013. Prinsip-Prinsip Dasain Pembelajaran Disesuaikan dengan Kurikulum 2013. Edisi kedua. Jakarta: Kencana. 